\title{
Appearance of HbeAg in an Occult Persistent Hepatitis B Virus Infection
}

\author{
Concetta Paparella ${ }^{a}$ Filomena De Rosa ${ }^{a}$ Roberta Longo ${ }^{b}$ \\ Giuseppina Cappiello $^{b}$ Antonella Ursitti $^{b}$ Marisa Rosa ${ }^{c}$ Massimo Morosetti ${ }^{c}$ \\ Alberto Spanò ${ }^{b}$ \\ a Department of Laboratory Medicine, 'G.B. Grassi' Hospital, 'b Department of Microbiology, 'S. Pertini' Hospital, and \\ 'Department of Nephrology and Dialysis, 'G.B. Grassi' Hospital, Rome, Italy
}

\section{Key Words}

Hepatitis B virus • HBsAg assays • Occult hepatitis •

HBsAg mutants $\cdot$ DNA sequencing

\begin{abstract}
Occult hepatitis B virus infection (OBI) is characterized by the presence of ongoing viral replication with very low levels of viremia $(<200 \mathrm{IU} / \mathrm{ml})$, and negativity for $\mathrm{HBsAg}$, while the socalled 'false' OBI with higher levels of HBV-DNA that are negative for $\mathrm{HBsAg}$ are usually due to the occurrence of mutations of the HBsAg sequence that may alter the recognition by some immunoassays. We describe here a case of occult HBV infection that combines both aspects. A male patient with severe systemic diseases, positive for anti-HBc and anti$\mathrm{HBs}$ and negative for all other HBV markers, including $\mathrm{HBsAg}$, since at least 4 years, showed a positivity for $\mathrm{HBeAg}$ at a follow-up control in November 2008; HBV-DNA testing by realtime PCR evidenced very low levels of viremia $(<40 \mathrm{IU} / \mathrm{ml})$, direct sequencing of the surface antigen-coding and Pol/RT coding regions allowed the identification of genotype $D$, serotype adw2, one immune escape mutation (G145R) and no drug resistance mutations. The positivity for $\mathrm{HBeAg}$ could be attributed to a superinfection in a naturally immune subject
\end{abstract}

\section{KARGER}

Fax +41613061234 E-Mail karger@karger.ch www.karger.com

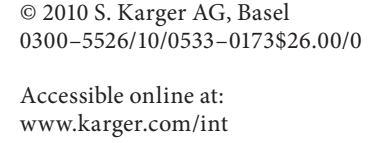

or to reactivation of a latent infection; the mutated virus had a reduced fitness and was therefore able to replicate only at low levels, resulting in a mild form of occult HBV infection.

Copyright $\odot 2010$ S. Karger AG, Basel

Infection by hepatitis B virus (HBV) is usually characterized by positivity for HBsAg in serum, while people who recover show the disappearance of this antigen followed by the seroconversion to the protective antibody (anti-HBs) [1]. The definition of 'occult' HBV infection indicate cases that show active HBV replication, with low-level $(<200 \mathrm{IU} / \mathrm{ml})$ positivity for HBV-DNA in serum, presence of HBV replication in the liver and negativity for HBsAg [2]. This pattern appears related in most cases to the lifetime persistence of HBV after recovery from an acute infection, either symptomatic or asymptomatic. In all HBV-infected subjects an episomic form of the viral DNA, the covalently closed circular DNA (cccDNA), persists and represents the viral reservoir [2]. Usually, occult infection by HBV is clinically silent, but some subjects, especially the immunocompromised patients, may experience a sudden reactivation, often with serious consequences and even death [1]. The prevalence
Concetta Paparella, MD

Department of Laboratory Medicine, 'G.B. Grassi' Hospital

Via Passeroni 28

IT-00122 Ostia Lido, Rome (Italy)

Tel. +39 065648 2146, Fax +39 065648 2143, E-Mail concetta.paparella@ aslromad.it 
Table 1. Serological patterns for HBV markers

\begin{tabular}{lllllllll}
\hline Date & HBsAg & $\begin{array}{l}\text { HBeAg } \\
\text { (S/CO) }\end{array}$ & HBeAb & anti-HBc & $\begin{array}{l}\text { anti-HBcl } \\
\text { IgM }\end{array}$ & $\begin{array}{l}\text { anti-HBs } \\
\text { mIU/ml }\end{array}$ & $\begin{array}{l}\text { HBV-DNA } \\
\text { IU/ml }\end{array}$ & $\begin{array}{l}\text { ALT } \\
\text { U/l }\end{array}$ \\
\hline Jan. 2007 & neg. & neg. (0.04) & neg. & pos. & neg. & 20 & n.d. & 16 \\
April 2007 & neg. & neg. (0.06) & neg. & pos. & neg. & 17 & n.d. & 15 \\
Aug. 2007 & neg. & neg. (0.02) & neg. & pos. & neg. & 15 & n.d. & 24 \\
Oct. 2007 & neg. & neg. (0.04) & neg. & pos. & neg. & 13 & n.d. & 21 \\
April 2008 & neg. & neg. (0.02) & neg. & pos. & neg. & 17 & n.d. & 18 \\
Nov. 2008 & neg. & pos. (1.65) & neg. & pos. & neg. & n.d. & n.d. & 23 \\
Jan. 2009 & neg. & pos. (1.56) & neg. & pos. & neg. & 25 & $39^{*}$ & 28 \\
Feb. 2009 & neg. & pos. (1.16) & neg. & pos. & neg. & 21 & $34^{*}$ & 48 \\
March 2009 & neg. & pos. (1.22) & neg. & pos. & neg. & 14 & n.d. & 18 \\
\hline
\end{tabular}

Serological patterns for HBV markers (Abbott ARCHITECT; since November 2008 to February 2009 Abbott ARCHITECT and Roche Elecsys) over 50 months for a male patient with an apparent natural immunity to HBV (positivity for anti-HBc and anti-HBs). $\mathrm{S} / \mathrm{CO}=$ sample/cutoff values; $\mathrm{mIU}=$ milli-International Units; IU = International Units; $U$ = Units; n.d. = not determined.

* Sequence analysis results: genotype D, serotype adw2; escape mutation G145R.

of occult HBV infections is higher in areas at high endemicity for HBV; in a recent report from South Korea, where the HBsAg prevalence is $>4 \%$, an occult $\mathrm{HBV}$ infection was detected in 7 of 1,047 HBsAg-negative adult subjects $(0.7 \%)$ [3].

A differentiation must be made with the 'false' occult HBV infection, in which HBV-DNA levels are comparable to overt infection [2]; in these case the presence of HBV strains with key mutations in the region coding for the surface antigen that are capable of avoiding the neutralizing anti-HBs antibodies (so-called 'escape' mutants), that may not be recognized by immunoassays for HBsAg that employ capture and/or detection antibodies that target the mutated sites [4].

We report here a clinical case that combines both aspects linked to an HBsAg-negative HBV infection. A male patient, aged 76 and treated by peritoneal dialysis since 2004 for chronic renal insufficiency of vascular origin, with monolateral nephrectomy subsequent to left renal vein thrombosis, was diagnosed with breast intraductal cancer in June 2008. After surgery (radical mastectomy) the patient underwent medical treatment with anastrozole $1 \mathrm{mg} /$ day and was followed up very closely ever since, including periodical assessment of circulating cancer biomarkers and of other parameters, among whom serum markers for major viral infections. The serological pattern for HBV markers at the first observation in our clinical setting ('G.B. Grassi' Hospital in Ostia) in January 2007 was $\mathrm{HBsAg}$ negative, $\mathrm{HBeAg}$ negative, anti-HBe negative, anti-HBc positive, anti-HBs positive at low lev- els $(20 \mathrm{mIU} / \mathrm{ml}$; table 1$)$. The patient did not show raised aminotransferase levels nor other signs or symptoms of liver disease and was then considered to be naturally immune to HBV. The serological pattern remained unchanged over time until, in November 2008, a positivity for $\mathrm{HBeAg}$ was registered: this prompted us to check $\mathrm{HBsAg}$, that was still negative by our routine assay (Abbott ARCHITECT HBsAg), also by another method (Roche Elecsys HBsAg). The pattern remained the same on two further follow-up visits in January and February 2009 and HBeAg was positive also by Roche Elecsys on all three specimens. At this point we carried out the determination of circulating HBV-DNA by a Real-Time PCR with a lower limit of detection of $12 \mathrm{IU} / \mathrm{ml}$ (Roche COBAS AmpliPrep/COBAS Taqman HBV test). On both specimens a positive result was achieved, with 39 and 34 $\mathrm{IU} / \mathrm{ml}$, respectively. Also, on the sample collected in February a raised ALT value (48 U/l) was recorded (table 1 ). Direct sequencing of the overlapped pol and s region was carried out after a nested PCR with primers named pol1, pol2, pol3 and polRV2 by Werle et al. [5] on the samples collected in January and February. We identified the $\mathrm{HBV}$ as genotype $\mathrm{D}$ (the most frequent in Italy), serotype adw2 $(122 \mathrm{~K}+160 \mathrm{~K}+127 \mathrm{P})$ and allowed to identify two point mutations that resulted in two single aminoacid substitutions in the common 'a' determinant of the surface antigen; $\mathrm{R} 122 \mathrm{~K}$ in the first loop causes the change of the normal genotype D associated HBsAg subtype from ayw2 to adw2 and therefore the escape from subtype specific anti-HBs against determinant y; G145R in the sec- 
ond loop that is the most frequent true immune escape mutation. Sequencing analysis of the reverse transcriptase/DNA polymerase domain showed no typical drug resistance mutations. Unfortunately we could not amplify and sequence the precore region because not enough plasma was available. The patient died from a sudden ischemic heart attack in mid April 2009.

The case we describe here represents a combination in which a classical occult HBV infection, as per current definition (viremia $<200 \mathrm{IU} / \mathrm{ml}$ and negativity for HBsAg) was caused by an HBV strain with G145R variant, the typical immune/vaccine escape mutant that allows HBV to emerge in immunocompromised patients whose $\mathrm{HBsAb}$ titer are permanently low such as the case we report here. Since we were not able to carry out the virological characterization on samples from 2007 to 2008, we cannot exclude that an occult HBV infection was preexistent to the $\mathrm{HBeAg}$ positivity recorder in November 2008; however, since $\mathrm{HBeAg}$ is related to active HBV replication, we might speculate that this patient either experienced a reactivation of a latent $\mathrm{HBV}$ infection, linked to the selection of escape mutants, or acquired an infection sustained by an HBV strain carrying one significant mutation in the 's' gene. In both instances, the weak replication competence of this mutant or the neutralizing effect, albeit incomplete, of the preexisting antiHBs antibodies, justifies the occult pattern; the negativity for HBsAg might be ascribed either to the very low antigen production/secretion, since none of the currently available assays for HBsAg is able to detect the very low amounts of surface antigen present in such cases $[4,6]$, or to the immune escape mutation G145R, although the screening assay that we employed (Abbott ARCHITECT
HBsAg) is able to detect the majority of surface mutants, including the classical G145R that was present also in this patient $[4,7,8]$, if present in sufficient amounts, compatible with the assay sensitivity $(0.05 \mathrm{IU} / \mathrm{ml})$ [7].

The case we describe here shows some resemblance with some recently published observations. In the already cited paper by Song et al. [1], sequencing of the HBV s gene in 3 cases with occult HBV infection revealed one wild-type and two mutant strains. Manzini et al. [8] described an acute, occult infection in a regular blood donor: also in this case the viral load was extremely low, ranging from 5 to $46 \mathrm{IU} / \mathrm{ml}$, and HBsAg was not detectable by several immunoassays. The donor HBV DNA sequencing consistently showed a CCA deletion leading to amino acid T116 lack in the small envelope protein (S), while other sequence features showed high homology between donor and contact case, suggesting a sexual transmission. Finally, Katsoulidou et al. [9] have also reported the occurrence of several amino acid substitutions related both to diagnostic escape and antiviral resistance in Greek blood donors with an occult HBV infection.

These findings, along with the one we report here, suggest that viral mutations that hamper the replicative fitness of HBV are cause of primary or chronic occult HBV infections. In view of the already recognized capability of these less fit viruses to reactivate, often with serious consequences, it is important, in our opinion, to carry out HBV-DNA testing and sequencing in all immunocompromised patients with any serological marker of HBV infection and to start antiviral prophylaxis before chemotherapy, as already recommended for HBsAg-positive, inactive HBV carriers undergoing the same therapeutic measures.

\section{References}

1 Yeo W, Chan TC, Leung NWY, Lam WY, Mo FKF, Chu MT, Chan HLY, Hui EP, Lei KIK, Mok TSK, Chan PKS: Hepatitis B virus reactivation in lymphoma patients with prior resolved hepatitis B undergoing anticancer therapy with or without rituximab. J Clin Oncol 2009;27:605-611.

-2 Raimondo G, Allain J-P, Brunetto MR, Buendia M-A, Chen D-S, Colombo M, Craxì A, Donato F, Ferrari C, Gaeta GB, Gerlich WH, Levrero M, Locarnini S, Michalak T, Mondelli MU, Pawlotsky J-M, Pollicino T, Prati D, Puoti M, Samuel D, Shouval D, Smedile A, Squadrito G, Trépo C, Villa E, Will A, Zanetti AR, Zoulim F: Statements from the Taormina expert meeting on occult hepatitis $B$ virus infection. J Hepatol 2008;49:652-657.
3 Song EY, Yun YM, Park MH, Seo DH: Prevalence of occult hepatitis B virus infection in a general adult population in Korea. Intervirology 2009;52:57-62.

4 Gerlich WH: Diagnostic problems caused by HBsAg mutants: a consensus report of an expert meeting. Intervirology 2004;47:310-313.

5 Werle B, Cinquin K, Marcellin P, Pol S, Maynard M, Trépo C, Zoulim F: Evolution of hepatitis B viral load and viral genome sequence during adefovir dipivoxil therapy. J Viral Hepat 2004;11:74-83.

-6 Kuhns MC, McNamara AL, Holzmayer V, Lou SC, Busch MP: Frequency of diagnostically significant hepatitis B surface antigens mutants. J Med Virol 2007;79(suppl 1):S42S46.
7 Scheiblauer H, Soboll H, Nick S: Evaluation of $17 \mathrm{CE}$-marked HBsAg assays with respect to clinical sensitivity, analytical sensitivity, and hepatitis B virus mutant detection. J Med Virol 2006;78:S66-S70.

$>8$ Manzini P, Abate ML, Valpreda C, Milanesi P, Curti F, Rizzetto M, Smedile A: Evidence of acute primary occult hepatitis B virus infection in an Italian repeat blood donor. Transfusion 2009;49:757-764.

9 Katsoulidou A, Paraskevis D, Magiorkinis E, Moschidis Z, Haida C, Hatzitheodorou E, Varaklioti A, Karafoulidou A, Hatzitaki M, Kavallierou L, Mouzaki A, Andrioti E, Veneti C, Kaperoni A, Zervou E, Politis C, Hatzakis A: Molecular characterization of occult hepatitis B cases in Greek blood donors. J Med Virol 2009;81:815-825. 